\title{
New challenges for the development of the oil market
}

\author{
Peter Kukhtin ${ }^{1, *}$, and Elena Znamenskaya ${ }^{2}$ \\ ${ }^{1}$ Financial University under the government of the Russian Federation, Leningrad pr., 49, \\ Moscow,125993, Russia \\ ${ }^{2}$ Moscow State University of Civil Engineering, 129337, 26, Yaroslavskoye Shosse, Moscow, Russia
}

\begin{abstract}
The article considers the current situation in the oil market and the issues that determine the search for the most relevant pricing mechanisms for international oil grades. As noted in the study, the volume of oil available for calculating the North Sea Brent standard is decreasing, and trading liquidity in the ports of the North Sea is decreasing. Peaks in the production of most fields are long behind, and more and more light oil from various regions of the world is being delivered to Europe. Despite many scenarios for the transition of energy to low-carbon sources, oil demand will continue to grow, at least until 2040. This determines the long-term relevance of issues of ensuring balance in the global oil market.
\end{abstract}

\section{Introduction}

In all sectors of the fuel and energy complex, Russia has both competitive advantages and problem areas. This applies to the oil, gas, electricity, coal industries, and even renewable energy.

Due to the wide spread of new technologies in the conditions of a geopolitical unstable situation in the world, many industries are faced with a number of new challenges. The last few years, a significant impact on the Russian fuel and energy complex has had a number of external circumstances that determined the high volatility of oil prices. Five years ago, oil reached \$ 120 per barrel, then plummeted to a minimum of \$27. A difficult situation has developed for both the state and oil companies. But in a fairly short time, an effective way to stabilize the market was found: in December 2016, an Agreement was signed to reduce oil production between OPEC countries and non-OPEC countries. Currently, supply and demand are quite balanced, and the additional budget revenue from the Agreement is estimated at 6 trillion. rub. Revenues of oil companies increased significantly. In July 2019, it was decided to extend the agreement on limiting oil production in the OPEC + format until April 1, 2020. As a result of measures taken in 2019, additional budget revenues will amount to 2 trillion rubles. It should be borne in mind that limiting oil production is not a permanent measure and is used only in a situation where this does not contradict Russia's interests in the world market [1-3].

* Corresponding author: uzr777@mail.ru 
The object of research is the global oil market.

The subject of the study is determined by the process of development and stability in the oil market.

During the study, the following tasks are solved:

- an analysis of the current situation in the energy markets, the main problems and potential for growth;

- provides aggregation of statistics of the global energy market for oil;

- trends in the development of the oil industry are identified.

\section{Materials and Methods}

The study was based on data from the International Energy Agency, forecasts by British Petroleum, official information from government bodies of the Russian Federation and the Analytical Center for the Fuel and Energy Complex.

The scientific research methods that were used are theoretical, since the tasks that are set cannot be achieved empirically. Theoretical research methods are based on the following two facts: - the internal structure and patterns of development of systems and phenomena; - their interaction and conditionality. In the process of analyzing individual precedents, grouping, systematizing them, we can determine their common, as well as various features, the installation of the general principle, in other words, the rule. The analysis proceeds in parallel with the synthesis, which contributes to a deeper understanding of the essence of the phenomena under study.

\section{Results}

As of 01.01.2019, the production of oil and gas condensate (oil feed) in the territory of the Russian Federation was carried out by 290 organizations that have licenses for the right to use subsoil, including:

- 100 organizations included in the structure of 11 vertically integrated companies;

- 187 independent mining companies not included in the structure of vertically integrated oil companies;

- 3 companies operating under production sharing agreements (operators).

The bulk of national oil production ( $85.2 \%$ of the total Russian indicator) is still formed by the largest vertically integrated companies. At the same time, the share of independent oil producing companies is growing, whose total contribution to the total oil production in the country reached $14.8 \%$ in 2018 . Of these, $3.4 \%$ are accounted for by operators.

In 2018, the world's proven oil reserves reached 244.1 billion tons, an increase of $0.1 \%$ compared to 2017 . Relative to 1998 , they grew 1.5 times. Venezuela remains the leader in oil reserves (17.5\% of global reserves). Russia retains 6th place in terms of explored reserves, which make up about $6.1 \%$ of world oil reserves (Figure 1).

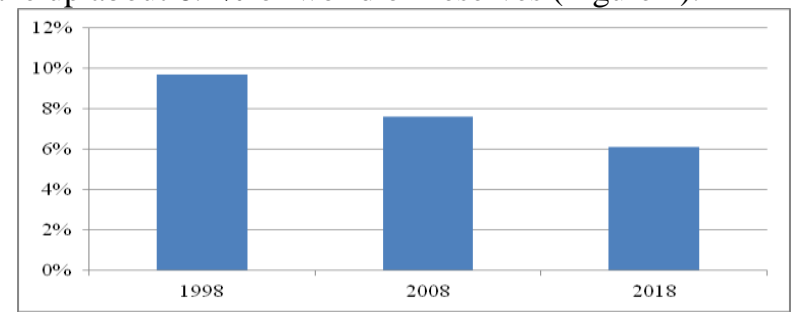

Fig. 1. Russia's share of oil reserves in the world. 
In 2018, liquid hydrocarbon production in Russia grew by 9.2 million tons $(+1.7 \%)$ after a decrease recorded in 2017 (by 2.1 million tons, or $0.4 \%$ ) and amounted to 555.7 million tons (Figure 2). The main factor in the increase in production was the redistribution of quotas under the OPEC + Agreement in the second half of 2018 in the context of favorable price conditions in the world oil market.

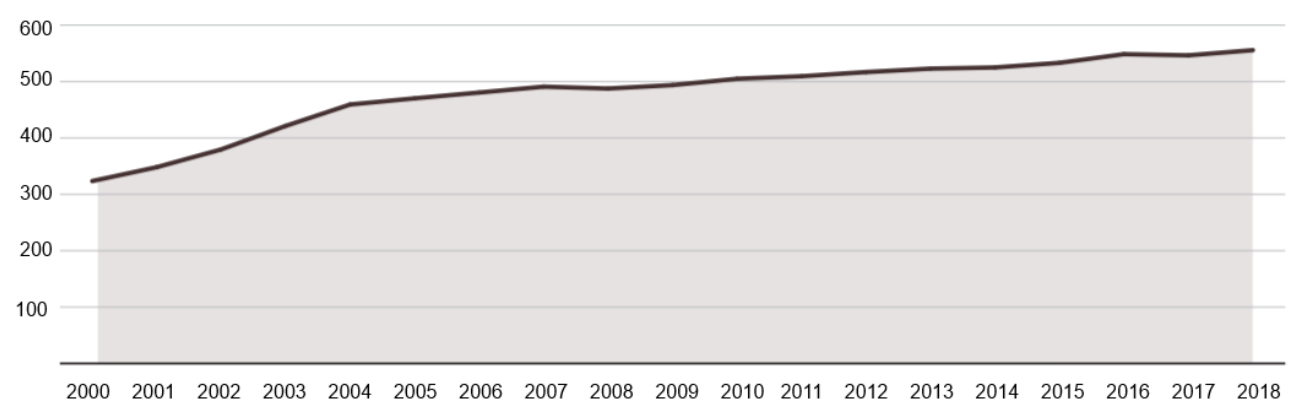

Fig. 2. Oil and gas condensate production in Russia in 2000-2018, mln tons.

The largest contribution to the increase in the production of liquid hydrocarbons in Russia in 2018 was made by the deposits of the Ural Federal District ( +4.3 million tons). However, the growth in the region was less than last year's decline ( -4.7 million tons). A slight decrease in liquid hydrocarbon production in Russia in 2018 was recorded only in the Northwestern Federal District ( -0.4 million tons) and the Volga Federal District $(-0.1$ million tons).

According to the International Energy Agency, in 2018 relative to 2017, the daily global increase in oil and other liquid hydrocarbon production increased to $2.7 \%$ from $0.5 \%$ in 2017 compared to 2016 . The largest increase in production was observed in the USA (+ $16.8 \%$ ), which increased their margin from most other leaders in the industry, mainly participating in the OPEC+ deal. OPEC countries in 2018 compared to 2017 reduced their production by $0.3 \%$, and the share in world oil production and oil and gas products - from $39.5 \%$ to $38.4 \%$. However, the main decline in production was observed in Venezuela ($28 \%$ ), where the crisis in the energy sector intensified. A marked reduction in oil production in OPEC countries was also observed in Angola (-8.6\%) and Iran (-3.6\%), for which the United States introduced restrictions on the export of oil and oil products in the fall of 2018. Under these conditions, Iraq was able to get ahead of Iran in the volume of oil production. Russia's share in world production remained virtually unchanged $(11.8 \%$ in 2018).

The increase in oil production in Russia in 2018 was mainly provided by Rosneft $(+5.5$ million tons compared to 2017). Production was also slightly increased by Tatneft $(+0.6$ million tons), LUKOIL ( +0.4 million tons) and Surgutneftegas (+0.3 million tons). Gazprom Neft's oil production in 2018 did not change compared to 2017, while Bashneft reduced production by 1.7 million tons (Figure 3 ). 


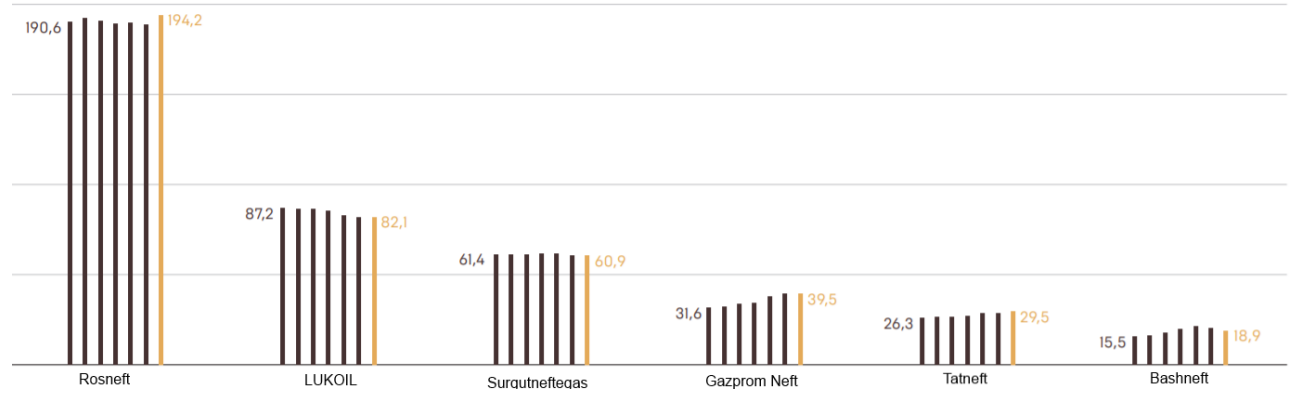

Fig. 3. Oil and gas condensate production by the largest companies in Russia in 2000-2018, mln tons.

According to estimates by the International Energy Agency, in 2018 relative to 2017, the consumption of liquid fuel in the world grew by $1.3 \%$, and over the past 10 years, on average over the year, increased by $1.4 \%$. The main drivers of demand growth remain the transport sector and petrochemicals. In OECD countries, in 2018 compared to 2017, consumption increased by $0.7 \%$. At the same time, the main growth in demand among them fell to the United States $(+2.5 \%)$, while in Europe it remained practically unchanged, while in developed countries the Asia-Pacific region declined (-1.8\%). In other countries, demand increased by $1.9 \%$, which mainly fell on the Asian market. About $80 \%$ of the additional demand for liquid fuel among developing countries in the market of the Asia-Pacific region in 2018 was provided by China $(+3.6 \%)$ and India $(+4.7 \%)$.

According to the forecasts of the Fuel and Energy Analytical Center, global demand will continue to slow down from 1.5 million barrels per day in 2018 to 1 million barrels per day in 2019 (Figure 4).

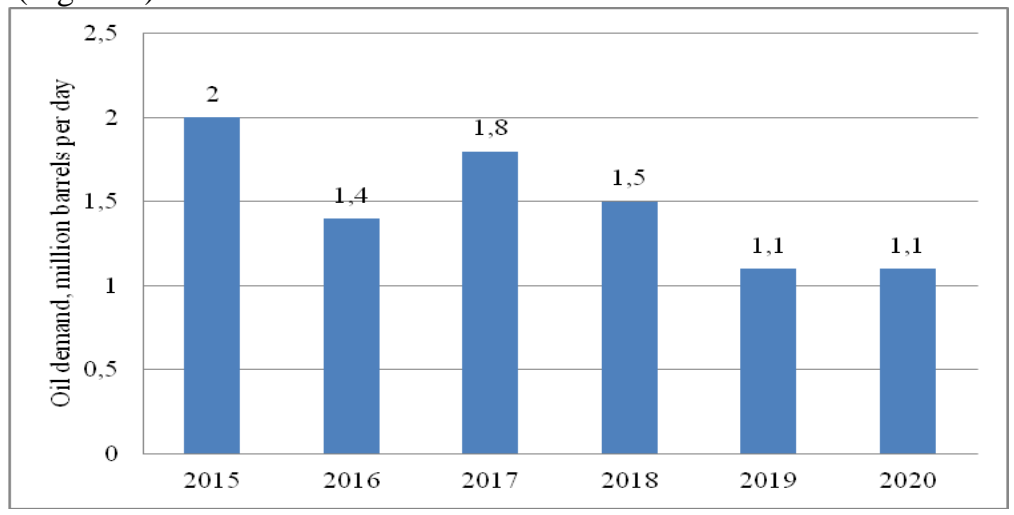

Fig. 4. Oil demand growth.

This is one of the weakest growth rates after the global crisis, it left behind only the growth of $2012-0.93$ million barrels per day. This decline is the result of a slowdown in the global economy. According to forecasts by OPEC experts, the global economic growth rate in 2019 will be $3 \%$ versus $3.6 \%$ in 2018 , while a slowdown in growth is observed in almost all regions of the world (table 1).

Table 1. Economic growth of the largest economies in the world.

\begin{tabular}{|c|c|c|c|}
\hline GDP growth & 2018 & 2019 & 2020 \\
\hline USA & $2,9 \%$ & $2,6 \%$ & $1,9 \%$ \\
\hline EU & $1,9 \%$ & $1,3 \%$ & $1,6 \%$ \\
\hline China & $6,6 \%$ & $6,2 \%$ & $6,0 \%$ \\
\hline India & $6,8 \%$ & $7,0 \%$ & $7,2 \%$ \\
\hline
\end{tabular}




\section{Discussion}

Despite the fact that the balance of oil markets is completely unpredictable and depends on many variables, four key factors should be highlighted.

The first factor is the slowdown in the global economy, as evidenced by many macroeconomic indicators. The business activity index (PMI) is steadily decreasing, the volume of debt with negative interest rates for the year has grown 2.5 times, to $\$ 15$ trillion, and now makes up $15 \%$ of the entire bond market.

The second factor is a decrease in the growth rate of US oil production against the background of relatively low oil prices in 2019, the gradual depletion of "sweet spots" and the growing need for additional drilling to maintain a constant level of production. This is due to the peculiarities of shale deposits: the flow rate of wells drops rapidly and new drilling is required. So, according to the forecasts of the international energy agency, in October 2019, oil production growth slowed down to 0.87 barrels per day, which corresponds to the lowest growth rate in two years. On the other hand, the continued decline in the breakeven price of production and the launch of new pipelines in the USA allow us to expect new records in production in the USA in 2020.

The third factor is the growing uncertainty in the oil markets. Sanctions against Venezuela and Iran, the trade war between the United States and China, the civil war in Libya - all this contributes to the destabilization of supply and demand. The attack on the oil fields of Saudi Arabia clearly showed how quickly the situation on the market can change. Immediately after the incident, Saudi Aramco announced that it would halve oil production by 5.7 million barrels per day, representing 5.7 world production. As a result, Brent crude oil prices rose $19 \%$ to $\$ 72$ per barrel. It was a record price increase at the opening of trading over the past 30 years. This reaction was triggered by fears of a shortage of oil on the market. Even without taking into account the accident, according to the calculations of the AC fuel and energy complex, the oil market should be in deficit of 1.4 million b / $\mathrm{s}$ in the third quarter of 2019. However, this does not mean that oil will really be missed by consumers. So far, the markets are well provided. According to official figures, OECD commercial reserves in July totaled 2.9 billion barrels, which is only 20 million barrels. Below the 5-year average. Saudi Arabia announced that in the near future it will compensate for the deficit in the oil market by increasing production to 11 million bpd (in September, the production level was 9.8 million barrels per day).

The fourth factor is the OPEC+ agreement, which successfully balances the market and ensures stability for its players. In 2019, its participants exceeded the terms of the agreement and kept production 1.2 million bpd below the level of October 2018. In total, from January 2017, OPEC+ countries have not delivered more than 1.5 billion barrels to the market. This allowed by May 2019 to almost completely eliminate the overabundance of reserves over the 5-year average, and make prices more predictable. In June, the agreement was extended for another 9 months, for March 31, 2020. Thus, the high level of execution of the agreement will continue to make a significant contribution to the stabilization of the market, despite these uncertainties (Figure 5) [8]. 


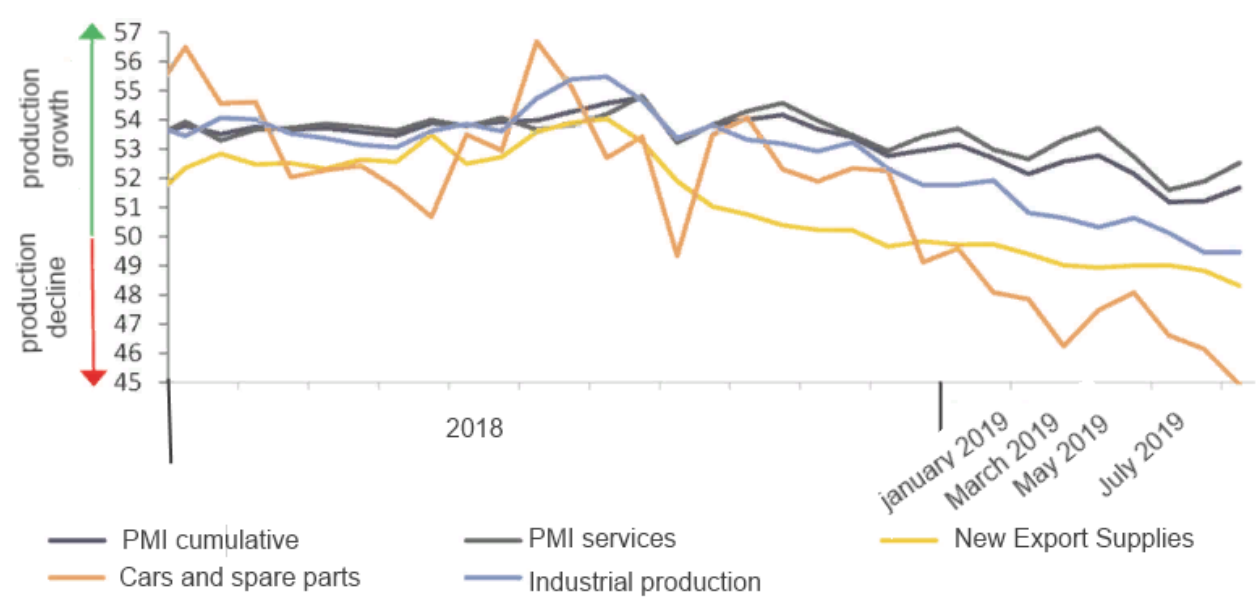

Fig. 5. Change in business index.

In the early fall of 2019, the composite index of global economic activity (J.P. Morgan Global Composite PMI) fell from 51.3 in August to 51.2 in September. The reasons for its decline were the deterioration of the situation with new orders and a decrease in international trade. Against this background, the dynamics of employment in the global economy has become close to stagnation. Composite Global Economic Activity Index presented by J.P. Morgan and IHS Markit, in September fell to 51.2, which was the lowest since mid-2016. Economic activity improved in the USA, Italy and Brazil. Australia's performance returned to growth after falling in August. Activity dynamics slowed down in France, Spain, Russia, Ireland, Germany and the UK. The service industry again looked better than the manufacturing sector, although there were signs of a decline in activity.

One of the priorities for the development of the national economy is to involve in the development of hard-to-recover oil reserves, which will ensure Russia's competitive advantage in the global hydrocarbon market. Under the conditions of sanctions, the implementation of this task is possible when import technologies are replaced by domestic innovative equipment for exploration and development of hard-to-recover reserves, as well as the formation of a competitive oilfield services market. For these purposes, the federal project "Development of the Bazhenov Formation in Western Siberia" is being launched. Today, the federal project unites more than 20 participants, including research institutes, startups, medium and large businesses, vertically integrated companies. All this creates a unique ecosystem for creating new innovative businesses in the Russian Federation with high export potential [4-7]. The project provides for the creation of a system of state incentives, which is aimed at removing administrative barriers and supporting developers of innovations. The phenomenal progress in the development and diffusion of energy-efficient technologies, and a change in the behavioral patterns of consumers have led to a sharp slowdown in the growth of energy consumption in most countries of the world and the rapid diversification of energy production sources in favor of a transition to a low-carbon economy. The scale of the changes taking place today in the energy sector, and especially in the field of information and technological development, indicates that the world energy system has entered a new phase of fundamental transformation. Moreover, the peculiarity of this transformation is the fact that the incentives to it are both economic and, to a greater extent, non-economic in nature.

\section{Conclusion}


There is a wide range of opinions on the trajectory of the long-term development of energy markets. At one end of the spectrum, oil demand is expected to peak in the next decade amid the proliferation of electric vehicles, increased substitution of oil for natural gas, and environmental restrictions on the growth of the plastics market. Proponents of this point of view believe that the share of coal in the global energy balance will be structurally reduced, and even the increase in natural gas consumption will be limited by the growth of generation based on renewable energy sources. At the other end of the spectrum, concerns about a potential oil shortage are attributable to a sharp decline in investment in traditional oil production projects, while shale oil production is slowing down. At the same time, demographic factors in developing countries are leading to an increase in global energy demand.

An objective deterioration in the conditions of field development, a decrease in the production rate of new wells, and an increase in water cut in the next 15 years may lead to an annual increase in operating costs with a simultaneous drop in oil production. In order to prevent a fall in investment in the mining segment, a number of benefits for the mineral extraction tax and special rates of export duties are envisaged. Since January 1 of this year, an experiment was launched to introduce a tax on additional income from the extraction of hydrocarbons, designed to partially take into account the real economy of production in taxation. In order to attract additional investment in oil production in the period 2019-2024 and to prevent a decrease in production, a roadmap has been developed for implementing measures to develop oil fields and increase oil production in the Russian.

\section{Reference}

1. BP, Energy Outlook: 2019 edition (BP p.l.c., London, 2018)

2. T. Meshcheryakova, E3S Web Conf., 110, 01076 (2019) doi: $10.1051 / \mathrm{e} 3$ sconf/201911001076

3. T. Meshcheryakova, MATEC Web of Conferences, 106, 06021 (2017) doi: $10.1051 /$ matecconf/201710606021

4. T. Meshcheryakova, N. Verstina, EMMFT 2017, 696, pp. 1136-1150 (2018) doi: 10.1007/978-3-319-70987-1_122

5. N.G. Verstiva, T.S. Mescheryakova, Biosciences Biotechnology Research Asia, 12, pp. 1411-1423 (2015) doi: 10.13005/bbra/1800

6. Mottaeva A., Glashev A., Kalinina N., Kuzmina A., Olenina O., E3S Web Conf., 91, 08072 (2019) doi: 10.1051/e3sconf/20199108072

7. Ganebnykh E., Burtseva T., Petuhova A., Mottaeva A., E3S Web Conf., 91, 08035 (2019) doi: 10.1051/e3sconf/20199108035

8. J.P.Morgan Global Composite PMI ${ }^{\mathrm{TM}}$, Global economic expansion eases to jointweakest rate sincemid-2016 (IHS Markit, London, 2019) 